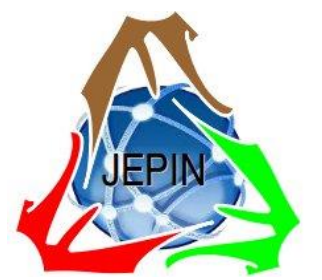

\title{
Sistem Berkas Digital Sebagai Media Penyimpanan Dokumen Kinerja Dosen
}

\author{
Novi Safriadi ${ }^{\# 1}$, Helen Sastypratiwi ${ }^{\# 2}$ \\ \#Jurusan Informatika, Fakultas Teknik, Universitas Tanjungpura \\ Jl. Prof. Dr. H. Hadari Nawawi, Pontianak \\ ${ }^{1}$ safriadieinformatics.untan.ac.id \\ 2helensastypratiwieinformatics.untan.ac.id
}

\begin{abstract}
Abstrak - Tugas utama Dosen adalah melaksanakan tri dharma perguruan tinggi yaitu pendidikan dan pengajaran, penelitian dan pengembangan, serta pengabdian kepada masyarakat. Pelaksanaan tugas dan hasil kegiatan tridharma dibuktikan dalam bentuk dokumen kinerja dosen seperti surat tugas, surat keputusan atau sertifikat. Tujuan penelitian ini adalah merancang sebuah sistem berkas digital. Sistem berkas digital ini menjadi perlu untuk dirancang dalam bentuk sistem repositori dokumen yang dapat menyimpan dokumen kinerja dosen dalam format digital. Dalam perancangan sistem berkas digital ini menggunakan metode prototipe. Sistem berkas digital menjadi langkah penting yang harus dilakukan sehingga dosen dapat dengan mudah mengakses dokumen kinerja untuk dapat digunakan dalam pelaporan capaian kinerja dosen pada setiap semester. Fungsi yang dapat menghasilkan tautan (generate link) sumber dokumen menjadi fitur penting yang dapat digunakan sebagai tautan informasi pendukung bukti pelaporan capaian kinerja dosen. Di Universitas Tanjungpura, capaian kinerja dosen dilaporkan melalui Sistem Beban Kerja Dosen (BKD). Adanya sistem berkas digital ini dinilai berhasil menjadi media penyimpanan dokumen kinerja dosen, khususnya pada Jurusan Informatika. Dokumen kinerja dosen yang telah dipindai menjadi berkas digital, kemudian diunggah ke sistem berkas digital, sehingga setiap saat berkas digital ini dapat diakses dan dimanfaatkan oleh dosen untuk berbagai keperluan. Berdasarkan pengujian yang dilakukan, dosen dapat mengakses sistem berkas dan mendapatkan setiap dokumen yang terdaftar atas namanya. Dalam sistem berkas digital, tautan dokumen dapat disalin dengan satu kali klik, untuk kemudian ditempelkan sebagai bukti capaian kinerja pada Sistem BKD. Pada semester genap 2019/2020 dan gasal 2020/2021 jumlah berkas digital yang diunggah sebanyak 228 dokumen, artinya sebanyak 228 tautan yang dapat digunakan oleh dosen sebagai bukti dalam pelaporan capaian kinerja dosen pada Sistem BKD.
\end{abstract}

Kata kunci- Dosen, Dokumen Kinerja, Sistem Berkas Digital, Sistem BKD, Jurusan Informatika

\section{Pendahuluan}

Standar Nasional Pendidikan Tinggi pada Bab 1 Pasal 1(13) menyatakan bahwa dosen sebagai pendidik profesional dan ilmuwan memiliki tugas utama untuk mentransformasikan, mengembangkan, serta menyebarluaskan ilmu pengetahuan, teknologi, dan seni melalui kegiatan tridharma, yaitu bidang pendidikan, penelitian, dan pengabdian kepada masyarakat. Untuk melaksanakan tugas tersebut, dosen wajib memiliki kualifikasi akademik dan kompetensi pendidik, sehat jasmani dan rohani, serta memiliki kemampuan untuk menyelenggarakan pendidikan dalam rangka pemenuhan capaian pembelajaran lulusan. Sehingga kualitas layanan perguruan tinggi sangat dipengaruhi oleh sarana dan prasarana yang menunjang. Salah satu prasarana yang amat penting adanya suatu sistem dapat membantu dosen dalam layanan data serta informasi.

Seringkali dalam pendokumentasian dan pengelolaannya tidak tertata dengan baik oleh dosen maupun oleh satuan kerja dalam pendidikan tinggi dalam hal ini pada Jurusan Informatika. Dimana dosen yang telah melaksanakan tridharma perguruan tinggi tentunya memiliki berkas-berkas yang dapat diubah bentuknya dalam bentuk digital sehingga dapat disimpan dalam media penyimpanan dokumen. Berkas-berkas ini sebagai bukti kinerja dosen yang nantinya dapat dipakai kembali untuk keperluan lain seperti mengurus golongan, jabatan fungsional. Kinerja dosen adalah hasil kerja yang dicapai oleh seorang dosen, sesuai dengan wewenang dan tanggung jawab masing-masing dalam rangka mencapai tujuan pendidikan secara legal, tidak melanggar hukum dan sesuai dengan norma atau etika [1][2][3].

Jika pengelolaan dan manajemen ini tidak dilakukan dengan baik, dapat menyebabkan permasalahan bermunculan diantaranya pencarian terhadap dokumen menjadi terbatas dan sulit. Disisi lain, dokumen tidak tersimpan dengan rapi, baik berdasarkan tahun ajaran maupun kategori dari dokumen tersebut yang akan mempersulit saat perhitungan beban kerja dosen dalam unit kerja. Hal ini melatarbelakangi perlunya sebuah sistem berkas digital sebagai media penyimpanan dokumen yang selanjutnya dapat disebut sebagai repositori. 
Repositori adalah kumpulan basis data yang memuat informasi mengenai objek yang dihasilkan atau digunakan oleh suatu organisasi, misalnya perangkat lunak, dokumen, peta, sistem informasi, maupun komponen diskrit dari sistem produksi yang dapat digunakan secara bersamasama. Data tersebut berupa objek yang disimpan dalam sistem penyimpanan dimana deskripsi dari objek tersebut disimpan dalam repositori. Pada umumnya repositori dapat berisi informasi lokasi, sejarah revisi, proses pembuatan, pengaturan hak akses, serta beberapa informasi penting lain yang berhubungan dengan objek yang disimpan. Selain itu, sebuah sistem repositori juga mengatur sistem yang dapat mengunggah atau mengunduh suatu file, konfigurasi versi, notifikasi, manajemen konten, maupun aliran proses [4].

Pendapat yang sama disampaikan oleh Armstrong yang menyebutkan bahwa sebuah repositori digital adalah mekanisme untuk mengelola dan menyimpan konten digital yang dapat dipercaya, yang dapat berupa repositori subjek, kelembagaan atau komersial [5]. Berbagai macam koleksi dapat dimasukkan dalam repositori digital untuk pengguna. Ini adalah kemampuan teknis dan kebijakan administratif yang memutuskan jenis bahan apa yang masuk ke repositori. Biasanya, isi dapat mencakup output penelitian seperti artikel jurnal atau hasil penelitian, e-tesis, objek e-learning dan bahan ajar, serta data administrasi [6]. Pentingnya sebuah repositori pada institusi, dapat memberikan keluran dari sebuah penelitian dan menjadi komponen dalam penelitian itu sendiri [7].

Sistem ini menjadi langkah penting yang harus dilakukan sehingga dosen dapat dengan mudah mengakses dokumen untuk dapat digunakan dalam berbagai kegiatan dalam mendukung tridharma, khususnya dalam mendukung kelengkapan berkas dalam perhitungan beban kerja dosen di Fakultas Teknik Universitas Tanjungpura. Pelaksanaan tugas tridharma dosen dituangkan melalui rencana dan laporan Beban Kerja Dosen (BKD) setiap semester. Undang-Undang No. 14/20005 pada pasal 72 (2) juga menyatakan bahwa beban kerja dosen sekurangkurangnya sepadan dengan 12 dan sebanyak-banyaknya 16 satuan kredit semester (SKS) [8].

Adapun di Universitas Tanjungpura memiliki sistem dalam perhitungan beban kerja dosen. Sistem ini dapat membantu dosen yang ingin mengetahui informasi beban kerja yang di tanggung, serta membantu pimpinan dalam mengetahui informasi beban kerja yang di tanggung setiap dosen [9].

Dari uraian di atas menjadi penting untuk diteliti bagaimana mekanisme sistem berkas digital dalam pengelolaan dokumen sehingga dapat menjadi salah satu alternatif pemberian layanan yang efesien yang dapat diakses kapan saja, khususnya sebagai media penyimpanan dokumen kinerja dosen.

\section{Metode Penelitian}

Metode yang digunakan dalam pembangun sistem berkas digital adalah metode prototipe. Metode prototipe adalah metode pendekatan perangkat lunak dimana pemangku kepentingan (stakeholder) dapat mengkarakterisasi target pencapaian umum namun tidak dapat mengklasifikasikan target secara detail [10]. Alasan lain digunakannya metode ini adalah telah digunakannya metode ini pada e-library, yang menunjukkan bahwa metode prototipe ini dapat membantu pengguna dalam melakukan proses pendataan dan pengelolaan data [11] Sehingga diharapkan metode prototipe dapat pula digunakan dalam sistem berkas digital.

Dalam pengembangan perangkat lunak, sebuah prototipe bisa menjadi contoh awal dari perangkat lunak sehingga dapat menentukan fitur apa saja yang digunakan maupun yang tidak digunakan sehingga dapat menampilkan gambaran dasar dari sebuah rengkat lunak. Biasanya pendekatan prototipe ini digunakan oleh seorang ahli sistem informasi dan ahli bisnis. Prototipe biasanya juga disebut sebagai desain aplikasi cepat (rapid application design/RAD). Hal tersebut dikarenakan pelaksanaan prototipe bertujuan untuk menyederhanakan dan mempercepat dalam desain sistem [12]. Pada umumnya, sebagian besar user kesulitan dalam mengungkapkan keinginannya untuk mendapatkan aplikasi yang sesuai dengan kebutuhannya. Kesulitan tersebut perlu diselesaikan oleh seorang analis dengan memahami kebutuhan user tersebut dan mampu menerjemahkannya menjadi sesuatu yang dapat memuaskan user. Oleh sebab itu, prototipe merupakan metode yang sangat baik untuk digunakan dalam menyelesesaikan masalah tersebut agar tidak terjadi kesalahpahaman antara user dan analis, yang timbul akibat user tidak mampu mendefinisikan secara jelas kebutuhannya[13]. Terdapat tahapan dalam metode prototipe yang dijelaskan pada gambar 1 mengenai tahapan dari metode prototipe.

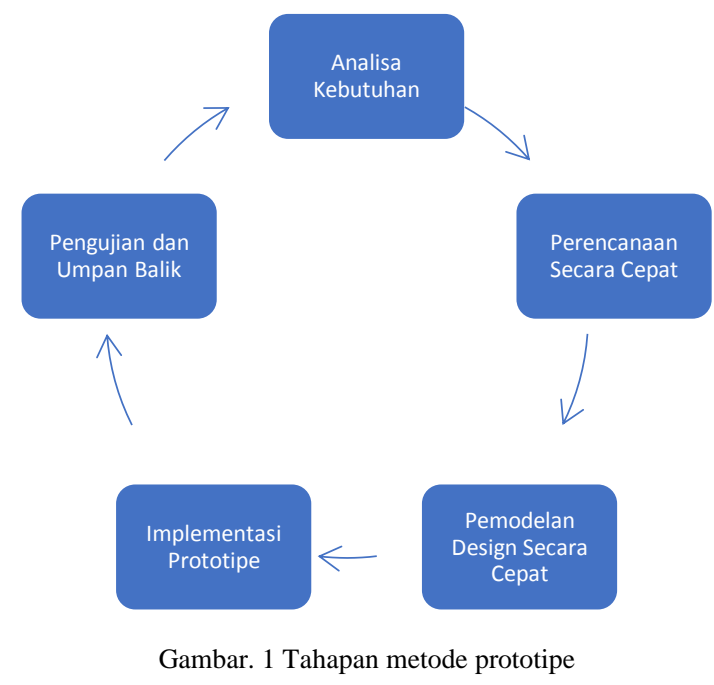

Berdasarkan gambar 1, pendekatan prototipe diawali dengan komunikasi dimana pemangku kepentingan menetapkan tujuan umum program sehingga didapat sebuah analisis terhadap kebutuhan secara singkat. Kemudian dilakukan perencanaan dan pemodelan secara cepat setelah itu dilanjutkan dengan implementasi prototipe terhadap rancangan yang sudah dibuat. 
Setelah implementasi, proyek memasuki tahap pengujian dan umpan balik. Disinilah klien mengevaluasi proyek dan memberikan umpan balik terkait proyek untuk mengarahkan proyek menjadi apa yang mereka butuhkan. Ini disebut iterasi, prosesnya berulang dalam pola ini hingga prototipe memenuhi tujuan yang dijelaskan sebelumnya, hingga prototipe akhirnya dapat dirilis sebagai program / sistem yang stabil. Terkait pula dengan data dan tools yang digunakan. Pada pengimplementasiannya, sistem memiliki data primer yang berasal dari data asli yang dimiliki oleh Jurusan Informatika. Data-data ini selanjutnya akan dipindai dan dikategorikan sehingga dapat digunakan dalam sistem.

Pengembangan dengan menggunakan pendekatan ini, pengembang dapat mengambil keputusan cepat tentang bagaimana persyaratan seharusnya. Persyaratan diselesaikan berdasarkan komentar klien pada prototipe dan mengembangkan prototipe untuk kepuasan klien pada setiap iterasi. Pengujian diperlukan dalam pengembangan. Sehingga pengujian blackbox menjadi pengujian yang digunakan dalam penelitian.

\section{A. Analisa Proses Bisnis}

Dosen melaksanakan tridharma perguruan tinggi daa=lam bentuk kegiatan bidang pendidikan, penelitian dan pengabdian. Bukti penugasan dan hasil kegiatan tridharma berupa surat tugas, surat keputusan atau sertifikat, dijadikan sebagai bukti kinerja dosen. penyimpanan berkas dilakukan secara mandiri oleh masing-masing dosen. dokumen kinerja dosen sangat jarang tersimpan sebagai arsip di administrasi program studi ataupun jurusan, baik secara fisik maupun digital, sehingga sangat memungkinkan dokumen kinerja dosen tersebut hilang dan/atau dibutuhkan waktu lama untuk melakukan pencarian dokumen.

Dengan dibangunnya sistem berkas digital, kegiatan penyimpanan berkas dapat dilakukan secara terkomputerisasi. Berdasarkan gambar 2 dapat dijelaskan bahwa sistem melibatkan dua pengguna yaitu admin dan dosen. Pengelolaan data dosen, data berkas, dan data berkas dilakukan oleh admin. Data tersebut kemudian di tandai dengan memasukkan nama dosen yang telah terdaftar sebelumnya oleh admin. Proses ini dinamakan enroll. Pengguna atau Dosen yang menerima enroll akan mendapatkan informasi yang dapat dilihat melalui sistem. Admin juga dapat membuat laporan pencatatan berkas secara otomatis melalui aplikasi.

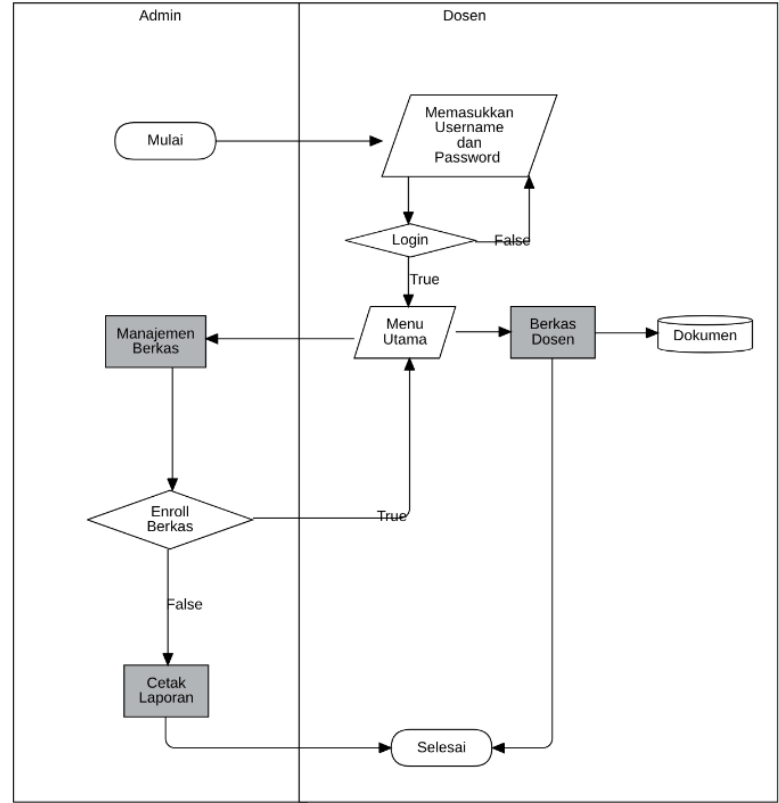

Gambar. 2 Analisa proses bisnis

\section{B. Analisa Kebutuhan Fungsional}

Dalam sistem tentunya kebutuhan fungsional menjadi tolak ukur dalam pengembangan. Berikut kebutuhankebutuhan user yang direpresentasikan kedalam kebutuhan fungsional:

TABEL I

KEBUtUHAN FunGSIONAL SiSTEM

\begin{tabular}{|l|l|}
\hline Kode & \multicolumn{1}{c|}{ Deskripsi } \\
\hline KF-01 & Sistem dapat memanjemen berkas \\
\hline KF-02 & Sistem dapat mengklasifikasi berkas \\
\hline KF-03 & $\begin{array}{l}\text { Sistem dapat melakukan generate link agar dapat } \\
\text { diakses langsung oleh sistem perhitungan beban } \\
\text { kerja dosen }\end{array}$ \\
\hline KF-04 & Sistem dapat mengarahkan berkas kepada dosen \\
\hline KF-05 & $\begin{array}{l}\text { Sistem dapat memberikan pemberitahuan kepada } \\
\text { dosen }\end{array}$ \\
\hline KF-06 & $\begin{array}{l}\text { Sistem dapat mencetak laporan data berkas } \\
\text { dapam periode yang dapat diatur }\end{array}$ \\
\hline
\end{tabular}

\section{Perancangan Diagram Alir Data}

Digunakan diagram alir data (DAD) dalam perancangan sistem untuk menggambarkan aliran data dalam sistem. Dalam DAD, terdapat diagram konteks yang merupakan sebuah diagram sederhana yang menggambarkan hubungan antara entitas luar, masukan dan keluaran dari sistem. Diagram konteks direpresentasikan dengan lingkaran tunggal yang mewakili keseluruhan sistem. Diagram sistem berkas digital dapat dilihat pada gambar 3 .

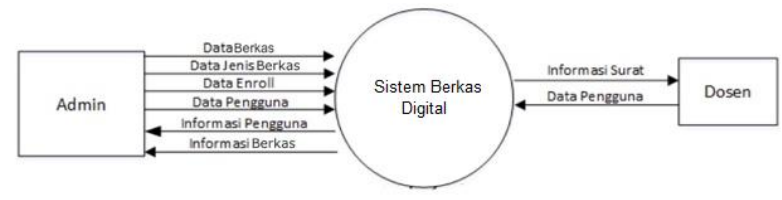

Gambar. 3 Diagram konteks sistem berkas digital 
Berdasarkan gambar 3 di atas dapat dijelaskan bahwa admin dapat melakukan input data berkas, data jenis berkas, data enroll, dan data pengguna. Melalui sistem, admin dapat melihat informasi pengguna dan informasi berkas. Kemudian dengan memberikan informasi dan data pengguna, dosen dapat melihat informasi berkas yang dienroll kepadanya.

\section{Perancangan Antarmuka Sistem}

Merancang antarmuka merupakan bagian yang paling penting dari merancang sebuah sistem. Rancangan antarmuka adalah sebuah desain antarmuka yang diperuntukkan untuk mesin dan perangkat lunak, seperti komputer, peralatan rumah tangga, perangkat seluler, dan perangkat elektronik lainnya, dengan fokus pada memaksimalkan kegunaan dan pengalaman pengguna. Tujuan dari desain antarmuka pengguna adalah untuk membuat interaksi pengguna sesederhana dan seefisien mungkin, dalam hal pencapaian tujuan pengguna (desain yang berpusat pada pengguna)[14].

Desain antarmuka pengguna yang baik memfasilitasi penyelesaian tugas yang ada tanpa menarik perhatian yang tidak perlu ke dirinya sendiri. Desain grafis dan tipografi digunakan untuk mendukung kegunaannya, memengaruhi cara pengguna melakukan interaksi tertentu dan meningkatkan daya tarik estetika desain; estetika desain dapat meningkatkan atau mengurangi kemampuan pengguna untuk menggunakan fungsi antarmuka. da metode prototipe percancangan disebut dengan pemodelan yang dapat mempercepat dan mempermudah dalam memvisualisasikan desain alternatif dan konsep.

Rancangan antarmuka (interface) yang dihasilkan dibagi atas dua pengguna yaitu dosen dan admin. Rancangan antarmuka telah disesuaikan berdasarkan analisa kebutuhan fungsional pada tabel 1, dapat dilihat pada gambar 4.

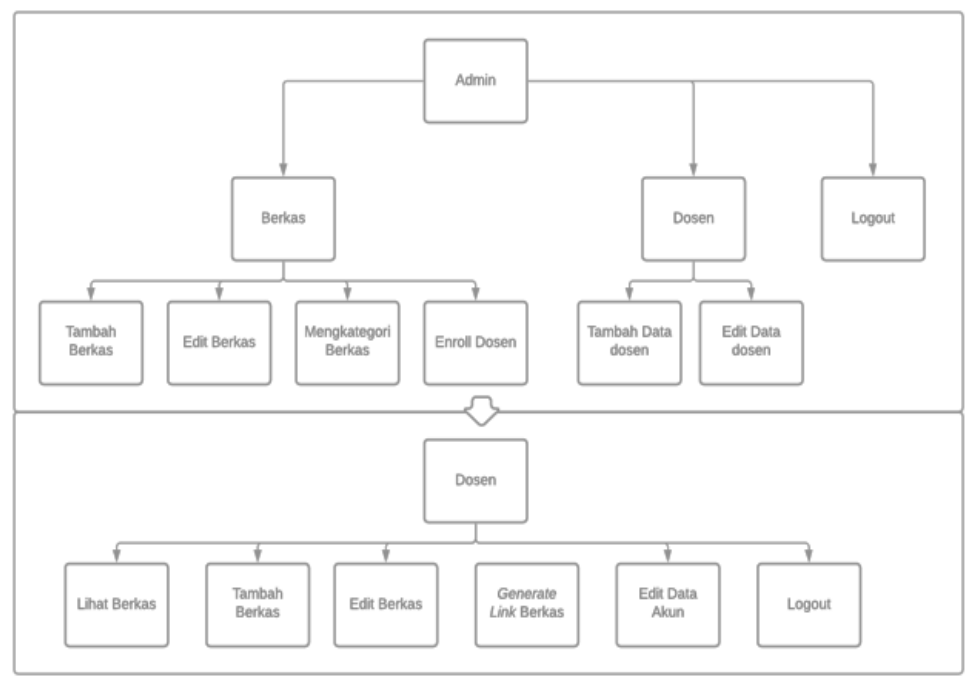

Gambar. 4 Struktur antarmuka sistem berkas digital

Gambar 4 merupakan rancangan struktur antarmuka pada sistem berkas digital, admin merupakan hirarki tertinggi, memiliki wewenang dan dapat mengakses menu atau fitur aplikasi di bawahnya, tetapi pengguna dalam kasus disini pengguna adalah dosen memiliki dengan hierarki lebih rendah tidak dapat mengakses menu atau fitur diatas hierarkinya. Admin memiliki otoritas tertinggi dapat mengakses, serta menggunakan semua fitur atau menu pada sistem. Otoritas ini telah disesuaikan dengan hak dan wewenang pengguna dalam kegiatan administrasi pada Instansi Jurusan Informatika Universitas Tanjungpura.

\section{HASIL DAN PEMBAHASAN}

\section{A. Implementasi Prototipe Admin}

Halaman dashboard (halaman utama) pada sistem berkas digital pada sisi admin ditunjukkan dalam gambar 5 . Pada halaman ini menunjukkan tabel yang berisi detail dari berkas dimana berkas dikategorikan menjadi surat masuk oleh Jurusan Informatika. Hal ini dikarenakan berkas bukan di terbitkan oleh Jurusan Informatika. Admin mengisi semua kolom yang disediakan mulai dari perihal, asal surat, nomor surat, tanggal surat, tahun ajaran (per semester), jenis surat, enroll, catatan disposisi hingga aksi.

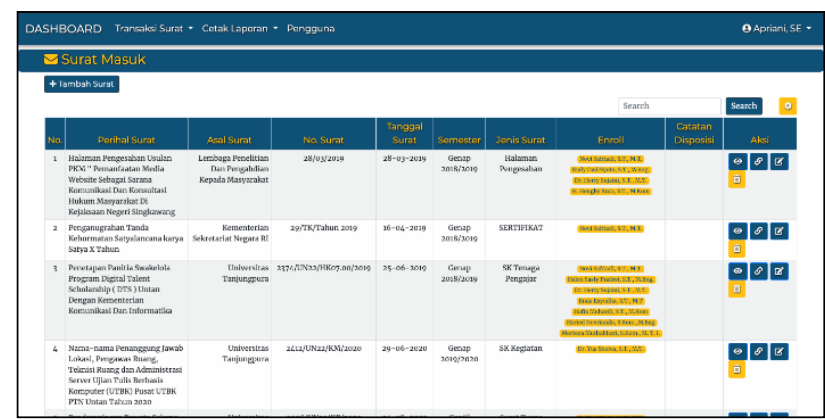

Gambar 5. Halaman dashboard admin 
Fungsi tambah pada admin dapat dilihat pada gambar 6. Fungsi ini menggunakan pop-up dalam sistem.

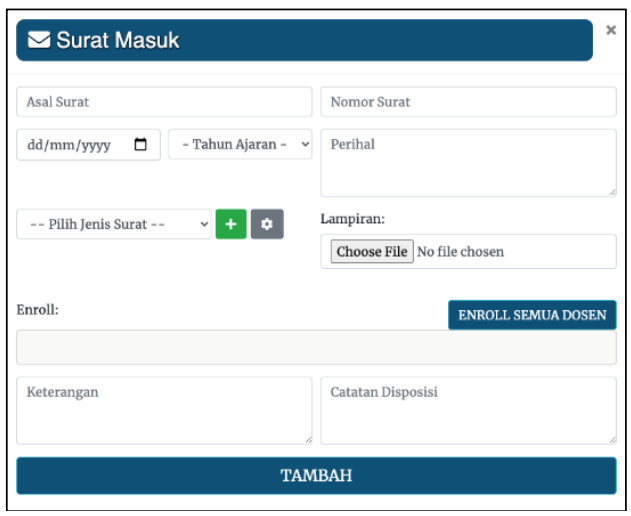

Gambar 6. Pop-up tambah data

Dalam fungsi tambah, berkas dapat diklasifikasi berdasarkan ketegori berkas tersebut dengan detal yang sudah ada terlihat pada gambar 7. Klasifikasi ini dapat ditambahkan manual oleh admin dengan menekan tombol tambah.

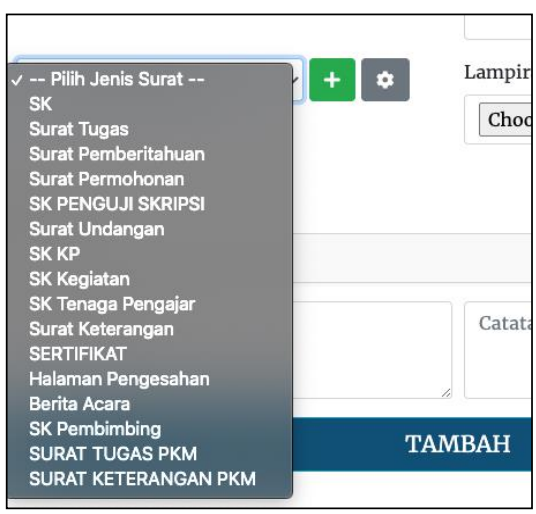

Gambar 7. Proses klasifikasi

Pada setiap berkas dalam prototipe admin, memiliki fitur edit, generate link, melihat berkas dan menghapus berkas yang ditunjukkan dalam gambar 8. Dimana lihat berkas ditunjukkan dalam gambar nomor 1 , selanjutnya nomor 2,3 dan 4 secara berurutan merupakan fitur generate link, edit berkas dan hapus berkas.

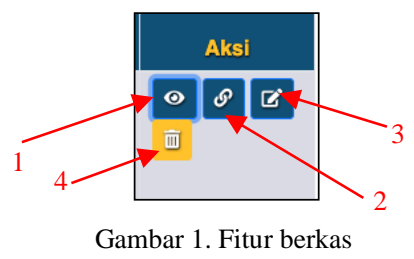

\section{B. Implementasi Prototipe Dosen}

Prototipe dosen dan prototipe admin memiliki tampilan dan fungsi yang berbeda. Pada halaman utama (dashboard) dosen, memiliki tab kategori yang berfungsi untuk membagi berkas berdasarkan jenis yang telah diinputkan oleh admin. Ketegori ini terdiri dari Sk, Surat Tugas, Berita
Acara, Halaman Pengesahan, dan Lainnya. Halaman ini ditunjukkan pada gambar 9 .

Pada gambar 9, terlihat berkas terbagi atas beberapa bagian. Berkas ini akan terlihat berbeda berdasarkan login masing-masing dosen karena sesuai dengan enroll yang telah dilakukan oleh admin. Berkas juga memiliki detail seperti tahun ajaran, nomor surat dan siapa saja yang di enroll dalam surat ini. Pada gambar ini juga terlihat filter berdasarkan tahun ajaran.

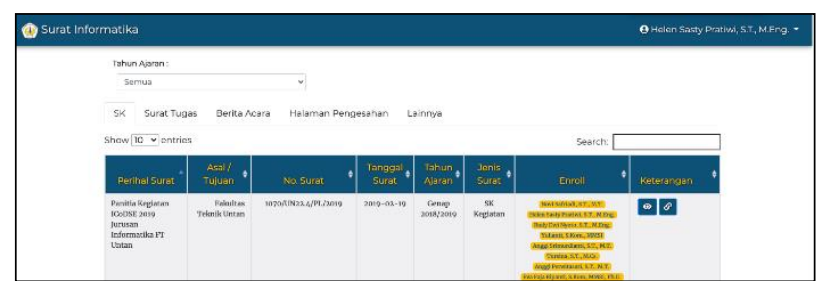

Gambar 9. Dashboard dosen

Pada prototipe ini, dosen memiliki fungsi yaitu melakukan generate link dan melihat berkas yang secara jelas ditunjukkan pada gambar 10 .

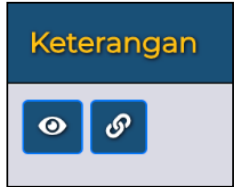

Gambar 10. Fitur berkas dosen

Fungsi generate link ini adalah fitur yang dapat digunakan pada Sistem BKD yang digunakan oleh civitas Universitas Tanjungpura dalam menghitung beban kinerja dosen. Adapun tampilan dapat dilihat pada gambar 11.

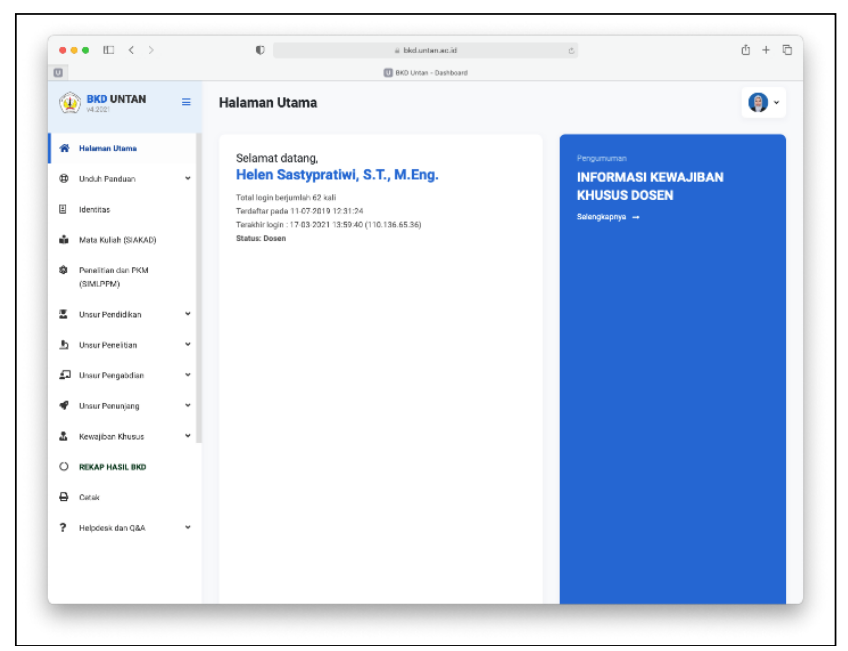

Gambar 11. Sistem BKD Universitas Tanjungpura

Sistem BKD menyediakan fitur untuk dapat mengunggah maupun menyalin link dari sistem diluar aplikasi pada kolom berkas. Fitur inilah yang dimanfaatkan oleh sistem berkas digital dimana pada sistem berkas digital dapat melakukan generate link yang hasilnya dapat disalin kedalam kolom tersebut. 
Link ini tentunya mempermudah dosen dalam menambahkan berkas sebagai bukti kinerja tanpa harus meng-upload secara satu persatu.

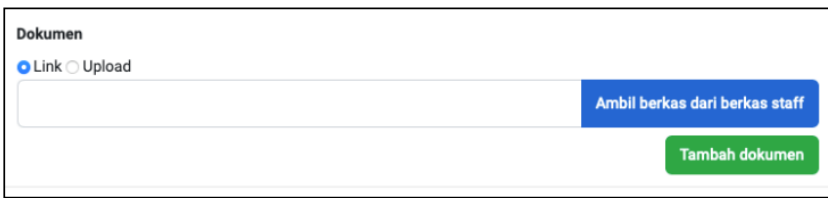

Gambar 12. Pengisian bukti dokumen

\section{Pengujian}

Pengujian sistem dilakukan dengan menjalankan aplikasi yang dibuat dengan tujuan supaya dapat memeriksa bila ada terjadi kesalahan setelah sistem dibuat, serta menguji apakah sistem berjalan dengan baik atau tidak. Pengujian aplikasi menggunakan metode Black Box, yaitu dengan menguji input dan output dari sistem. Pengujian blackbox menggunakan teknik decision table. Digunakannya decision table adalah dikarenakan cara ini merupakan cara yang tepat dalam alur if-then-else dan kasus switch, dengan mengaitkan akan suatu kondisi untuk suatu tindakan [15] yang ditunjukkan oleh sistem pada fitur utama saat menginputkan berkas digital yang dapat dilihat pada gambar 13.

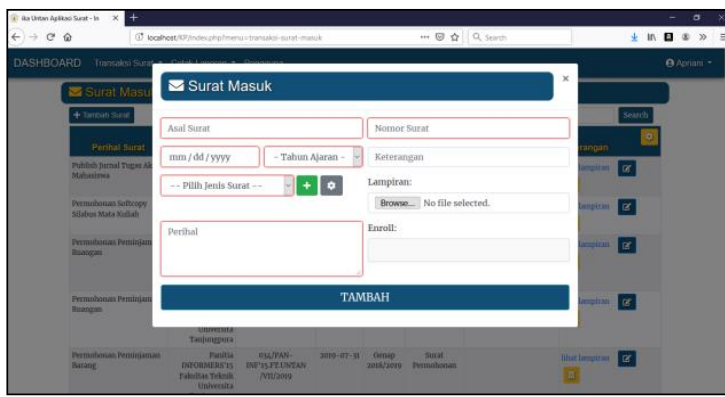

Gambar 13. Pengujian blackbox

Pada form tambah dan ubah data, beberapa atribut data tidak boleh kosong. Form tambah di perlihatkan secara pop-up dapat dilihat pada gambar 13. Apabila terdapat atribut wajib, data bernilai null maka tombol simpan tidak dapat di tekan dan data tidak masuk ke database. Detail pengujian dapat dilihat pada tabel 2 dibawah.
TABEL III

TABEL PENGUJIAN

\begin{tabular}{|c|c|c|c|c|c|}
\hline \multirow{7}{*}{$\frac{\text { No. }}{1}$} & Input & \multicolumn{2}{|c|}{ Contoh data } & Output & Keterangan \\
\hline & \multirow{6}{*}{$\begin{array}{l}\text { Semua } \\
\text { inputan } \\
\text { kosong }\end{array}$} & Username & Null & \multirow{6}{*}{$\begin{array}{l}\text { Tidak } \\
\text { bisa } \\
\text { menekan } \\
\text { tombol } \\
\text { simpan }\end{array}$} & \multirow{6}{*}{$\begin{array}{l}\text { Data masih } \\
\text { kosong }\end{array}$} \\
\hline & & $\begin{array}{c}\text { Nama } \\
\text { Pengguna }\end{array}$ & Null & & \\
\hline & & NIP & Null & & \\
\hline & & Email & Null & & \\
\hline & & Password & Null & & \\
\hline & & $\begin{array}{l}\text { Retype- } \\
\text { password }\end{array}$ & Null & & \\
\hline \multirow[t]{6}{*}{2} & \multirow[t]{6}{*}{$\begin{array}{l}\text { Sebagian } \\
\text { data ada }\end{array}$} & Username & $\begin{array}{l}\text { Eduar } \\
\text { dus }\end{array}$ & \multirow{6}{*}{$\begin{array}{l}\text { Tidak } \\
\text { bisa } \\
\text { menekan } \\
\text { tombol } \\
\text { simpan }\end{array}$} & \multirow{6}{*}{$\begin{array}{lr}\text { Data masih } \\
\text { ada } & \text { yang } \\
\text { kosong } & \end{array}$} \\
\hline & & $\begin{array}{c}\text { Nama } \\
\text { Pengguna }\end{array}$ & Edo & & \\
\hline & & NIP & Null & & \\
\hline & & Email & Null & & \\
\hline & & Password & Null & & \\
\hline & & $\begin{array}{l}\text { Retype- } \\
\text { password }\end{array}$ & Null & & \\
\hline
\end{tabular}

Pada form pengisian bukti yang dapat dilihat pada gambar 12, fungsi fitur generate link dapat berjalan dengan baik. Dibuktikan dengan terisinya dokumen dengan nama File pada tabel pengisian BKD yang ditunjukkan pada gambar 14.
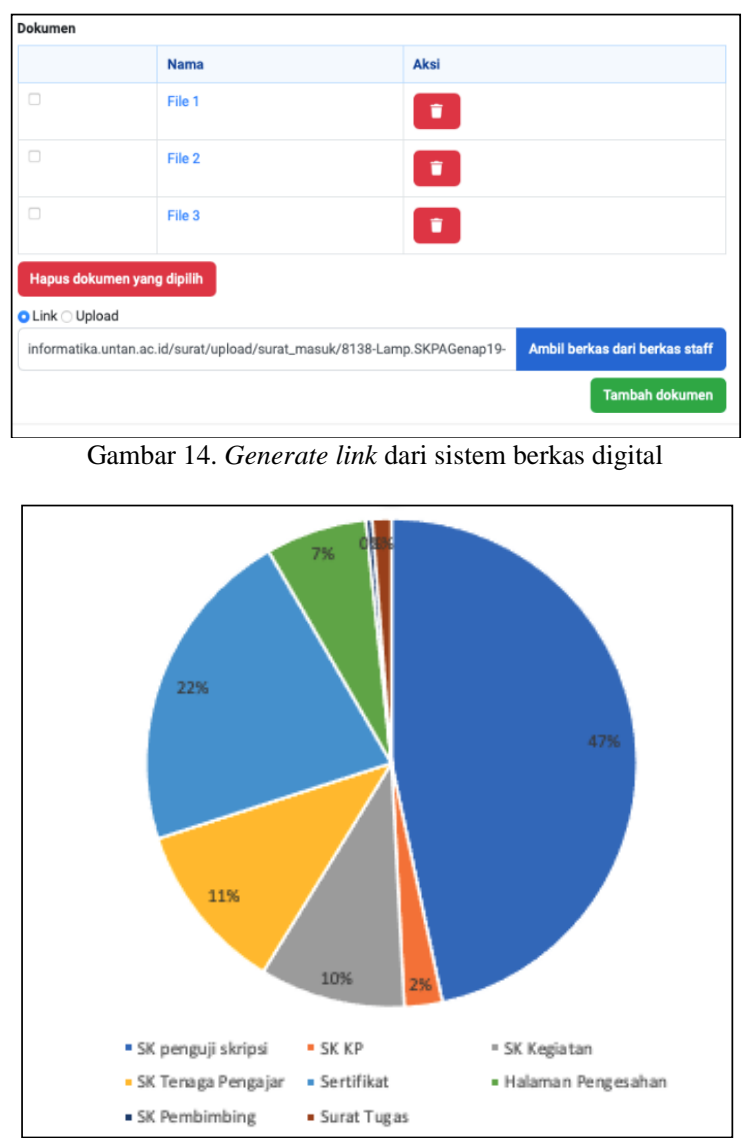

Gambar 15. Sebaran berkas digital 


\section{KESIMPULAN}

Sistem berkas digital berhasil diimplementasikan dengan menggunakan metode prototipe. Sistem berkas digital yang dibangun dapat digunakan dalam berbagai kegiatan penanganan berkas. Sistem digunakan untuk pencatatan dan penyimpanan data berkas yaitu dengan penginputan oleh Admin. Sistem berkas digital ini dapat mengklasifikasikan berkas dalam berbagai jenis yang dapat diatur secara langsung. Kegiatan pengarahan berkas yang disebut enroll juga dapat dilakukan melalui sistem ini, Admin dapat meng-enroll berkas kepada Dosen dengan mudah.

Sistem berkas digital juga dilengkapi dengan fitur pembuatan laporan data berkas masuk dan berkas keluar dengan format yang disesuaikan. Dalam pemanfaatannya, dokumen kinerja dosen dipindai menjadi berkas digital kemudian diunggah ke sistem berkas digital. Dosen mengakses sistem berkas digital dan mendapatkan setiap dokumen yang terdaftar (enrolled) atas namanya. Tautan dokumen dapat disalin (copied) dengan satu kali klik, untuk kemudian digunakan ditempelkan (paste) sebagai bukti capaian kinerja pada Sistem BKD.

Pada semester genap 2019/2020 dan gasal 2020/2021 jumlah berkas digital yang diunggah sebanyak 228 dokumen, artinya sebanyak 228 tautan yang dapat digunakan oleh dosen sebagai bukti dalam pelaporan capaian kinerja dosen pada Sistem BKD. Adapun jumlah sebaran berkas yang digunakan oleh dosen dengan jumlah data yang tersimpan dalam sistem berkas digital dapat dilihat pada gambar 15 .

\section{REFERENSI}

[1] P. Suyadi, "Kebijakan Kinerja Karyawan," Yogyakarta BPFE 1999.

[2] D. Anggerainy, "Evaluasi Kinerja Lembaga Pemasyarakatan Klas I Tanjung Gusta Medan," 2014.

[3] W. Supriyono, T. Tukiran, and A. Sudjadi, "PENGARUH KECERDASAN EMOSI, GAYA PEPEMIMPINAN DAN BUDAYA ORGANISASI TERHADAP KINERJA GURU (Studi pada SMP dan SMA Negeri di Kabupaten Banjarnegara)," Sainteks, vol. 11 , no. 1,2014

[4] P. A. Bernstein and U. Dayal, "An overview of repository technology," in $V L D B, 1994$, vol. 94, pp. 705-713.

[5] M. Armstrong, "Institutional repository management models that support faculty research dissemination," OCLC Syst. Serv., 2014.

[6] M. Z. H. Shoeb, "Access management for digital repository," DESIDOC J. Libr. Inf. Technol., vol. 29, no. 4, p. 21, 2009.

[7] T. S. Plutchak and K. B. Moore, "Dialectic: The aims of institutional repositories," Ser. Libr., vol. 72, no. 1-4, pp. 27-35, 2017.

[8] Lembaga Pengembangan Pembelajaran dan Penjaminan Mutu, Pedoman Penilaian BKD Universitas Tanjungpura Tahun 2021, Pontianak, 2021.

[9] M. A. Irwansyah, "Sistem Informasi Repository Digital Beban Kerja Dosen," vol. 1, no. 1, pp. 18-23, 2015.

[10] R. S. Pressman, Software engineering: a practitioner's approach. Palgrave Macmillan, 2005.

[11] F. D. Y. Astutik, A. Kharismasari, T. B. S. A. Laksono, I. Santoso, and A. Chusyairi, "E-Library Peminjaman dan Pengembalian Buku Berbasis Web dengan Metode Prototipe," JTIM J. Teknol. Inf. dan Multimed., vol. 1, no. 3, pp. 254-260, 2019.

[12] J. A. O'brien and G. M. Marakas, Management information systems, vol. 9. McGraw-Hill/Irwin, 2011.

[13] A. Mulyanto, "Sistem Informasi konsep dan aplikasi," Yogyakarta: Pustaka Pelajar, vol. 1, pp. 1-5, 2009.

[14] D. Norman, "Emotion \& design: attractive things work better," interactions, vol. 9, no. 4, pp. 36-42, 2002.

[15] M. L. Larrea, "Black-box testing technique for information visualization. Sequencing constraints with low-level interactions," J. Comput. Sci. Technol., vol. 17, 2017. 